\title{
The International Journal of Wellbeing: Ten years on and the next ten years
}

\author{
Dan Weijers · Aaron Jarden
}

\section{Looking back 10 years}

In the book chapter "The International Journal of Wellbeing: An Open Access Success Story", we outlined how the International Journal of Wellbeing (IJW) came into being as a caffeinated conception (fleshing out the seed of a good idea over a cup of coffee) between two of the founders - Dan Weijers and Aaron Jarden. The moment went a little bit like this:

DW: There are not enough journals that publish interdisciplinary wellbeing research.

AJ: You're right. The few that do are choked up with submissions.

DW: We could create one, you know. There is free software for it.

AJ: That's a great idea. What would we call it?

DW: What about the Australasian Journal of Wellbeing?

AJ: Why not the International Journal of Wellbeing?

DW: But, could we really make it thoroughly international?

AJ: Sure, and it would be more fun. We should ask all of the people we really admire to be involved - and they're everywhere.

DW: But, why would they get on board with this?

AJ: I can see a lot of benefits, and I think they will too.

DW: Let's grab a coffee and figure this out...

After many months of organization, advocacy and much cajolement for submissions over 2010, our first issue was published on the $30^{\text {th }}$ of January 2011. Led by Dan, Aaron and Nattavudh Powdthavee as the first co-editors, this issue was a huge success-articles in it were downloaded over 5,500 times in the first two months and citations began immediately.

Since this time the IJW has gone from strength-to-strength, and is now one of the most widely read journals in the interdisciplinary wellbeing space. The IJW's publishing statistics for its 10 first years speak for themselves:

- 32 issues published (including a special issue on COVID-19)

- 171 articles published (plus 46 editorials, book reviews, and expert insights)

- 7,740 Google Scholar citations (average $~ 45$ citations per article)

- 1.2 million pageviews (average of 656 per day in 2020)

- 1 million full-text views (average of 4,695 per published item)

- Visitors from 218 nations

- 5,471 users get notified every time we publish an issue

We could not be more proud of the enormous reach and impact the IJW has had. 


\section{Reflecting on our goals}

In many ways, the IJW has far outstripped our expectations... but not in all ways. Looking back to when we published the first issue, Dan, Aaron and Nattavudh, as very early-career academics, wrote a three-page editorial (Weijers, Jarden, \& Powdthavee, 2011) in which we outlined our ambitions for the IJW, including:

1. [the IJW] “...publishes scholarly research on wellbeing (broadly construed). The purpose of the journal is to promote thought and discussion on this vital topic. The launch of the IJW is a direct response to increasing demand both for research on wellbeing and for publishing opportunities for wellbeing researchers". (p. 1)

2. "... a broad multidisciplinary scope, an interdisciplinary focus, and a commitment to provide all its content for free without delay or any cost to authors". (p. 1)

3. "The IJW also plans to publish a diverse range of multimedia content, including readers' comments on IJW articles, video abstracts, and debates". (p. 2)

While some of these ambitions have been realized (with the main one being the promotion of high-quality research on wellbeing to so many people for free), some have not, and some, such as video abstracts, have only materialized in the last year! Ten years on we now reflect on these initial ambitions, and our journey and progress over the years, and offer some further insights from our perspective about this journey.

\subsection{Insight 1: Interdisciplinary research}

We have not yet achieved our goal of a truly interdisciplinary journal. In our original editorial we explained the importance of interdisciplinary research like this (Weijers, Jarden, \& Powdthavee, 2011, p. 2):

"[I]nterdisciplinary research also has considerable benefits. When researchers from diverse disciplines collaborate on a topic, they must first establish the overlap and disconnects between the established knowledge from each discipline. Working through the disciplinary similarities and differences enables the collaborators to create a broader, more nuanced, and more accessible understanding of the topic. Furthermore, if this collaborative understanding is reported, other researchers can use the resulting information as a guide to incorporating the findings of the other discipline(s) into their own investigations. Researchers who draw on findings from other disciplines in this way can bring new and often fruitful perspectives to their discipline's old problems and new challenges. Performed in this way, interdisciplinary research has the potential to produce disciplinary advances much faster than if researchers never looked outside of their respective disciplines"

While it is true that we have published articles from many disciplines, and from top scholars in these disciplines, our original vision was a more representative and balanced catalogue across the disciplines pursuing wellbeing. It strikes us that the majority of our publications are related to psychology, and we expected to have received more submissions from disciplines such as philosophy and economics, where discourse on wellbeing is prevalent in journals central to those fields. In addition, we expected more truly interdisciplinary submissions that tap into knowledge from more than one discipline. Nevertheless, some of our articles have been truly interdisciplinary, such as Willem van der Deijl's "What happiness science can learn from John Stuart Mill" (2016), and the presence of articles from different disciplines alongside occasional interdisciplinary articles will hopefully help enable a steady shift toward interdisciplinary research in our pages and elsewhere. 


\subsection{Insight 2: Publishing speed and reviewer availability}

We expected to be able to reduce publication times, but the reality of the IJW being a completely volunteer-run journal that also needs to gain minimal funding support (which is time consuming), meant that the pressures of academic life did not always allow us the time to process articles as speedily as we would have liked. While our publication time is still impressive and well in advance of most other journals, we anticipated to have made this much quicker.

One of the factors affecting our review turnaround times is the decreasing availability of reviewers. We have noticed that we increasingly have to ask more and more reviewers before securing two or more experts willing to conduct a review. We do not blame academics for their reluctance to review papers in general. The act of reviewing is not properly accounted for in our advancement and promotion mechanisms, while the increasing pressure to publish undermines academics' ability to prioritise work that is good for the profession but not directly for themselves. What we do hope is that academics are more discerning about which journals they review for, in particular that they favour open access journals.

We have also changed our policies in light of these factors. In 2019 we began being much more selective about which submission were sent for review, desk-rejecting an increasing proportion of submissions. We also tend to invite several reviewers at once, rather than two at a time to avoid authors waiting months before the blind review of their submission even begins.

\section{Insight 3: Open access and the invasion of predatory journals}

Being genuinely open access - free for both readers and authors - has been and continues to be an important point of difference for the IJW. As we explain in Weijers and Jarden (2017), our commitment to open access helped us garner support from some of the most important wellbeing researchers in the world. We expect that our open access policy also appeals to a lot of potential authors. However, the ever-increasing presence of predatory "open access" journals seems to have made some potential authors suspicious of our open access policies. We regularly receive emails enquiring about the "author fee" for publishing with the IJW. Of course, we believe that authors shouldn't have to pay, since they have already done the most difficult part of creating research. Similarly, it seems unfair to ask universities and other institutions to pay since they already pay the researchers for their time and pay the academic publishers for subscriptions to the non-open-access journals. We stand by our initial commitment to genuine open access and we encourage others to carefully consider where to publish and what journals to read to ensure we don't further encourage the predatory journals.

\section{Some other achievements}

We are also incredibly proud of some of the IJW's accomplishments. We feel blessed to have attracted and retained many of the brightest and fastest-rising stars in wellbeing research as editorial staff. We are delighted with the newly branded logo and website that better fit contemporary times (special thanks to Meg Warren for all her work on this). We have also upgraded the hosting software, so our processes should become more transparent and efficient. We are also very pleased to be able to contribute to pertinent issues with a diverse range of special issues over the years (such as a recent one on COVID-19 and wellbeing; Volume 10, Issue 3).

From a more personal perspective, Aaron is especially proud to have been able to publish material that is particularly useful to practitioners (in addition to academics), such as the "Ethical guidelines for positive psychology practice" (Volume 9, Issue 3), which is now freely available in 11 languages. 
Dan is especially proud of the number of times we have turned down offers from multinational publishing companies to take control of the IJW. Foregoing personal profit, we have saved individual researchers and institutions hundreds of thousands of dollars (at least). The exact figure is difficult to calculate, but ball-park estimates can be made. Assuming a US $\$ 3,000$ per item open access fee, it would have cost researchers or institutions US\$651,000 to make all of the IJW's content free for all readers. Looking at it another way, assuming a US $\$ 40$ per item download fee, it would have cost individual readers over US $\$ 40$ million. We suspect the realistic estimate lies somewhere between these two figures. Readers interested in our position on open access research can learn more in Weijers and Jarden (2017).

We are also both proud of the IJWs involvement with the Wellbeing and Public Policy Conference series, which has brought academics and policymakers from around the world together in New York and Wellington (twice). A special thanks to Philip S. Morrison who has also been involved in organising every conference. The fourth conference in the series is planned for Melbourne once COVID restrictions relax internationally. Watch this space: https://www.wappconference.com/.

\section{10 of the best}

We have published some very important articles over the years. We would like to take this opportunity to announce 10 awards. Mainly based on readership and citations, the editors have selected the best article published in the IJW each year. In some years, it was very close and we have also included honourable mentions for short-listed articles that just missed out. The winners and honourable mentions of the "IJW Best Article of the Year" are as follows:

\section{Winner}

Forgeard, M. J. C., Jayawickreme, E., Kern, M. \& Seligman, M. E. P. (2011). Doing the right thing: Measuring wellbeing for public policy. International Journal of Wellbeing, 1(1), 79-106. https://doi.org/10.5502/ijw.v1i1.15

\section{Honourable mention}

Bryant, F. B., Chadwick, E. D., \& Kluwe, K. (2011). Understanding the processes that regulate positive emotional experience: Unsolved problems and future directions for theory and research on savoring. International Journal of Wellbeing, 1(1), 107-126. https://doi.org/10.5502/ijw.v1i1.18

\section{Winner}

Dodge, R., Daly, A., Huyton, J., \& Sanders, L. (2012). The challenge of defining wellbeing. International Journal of Wellbeing, 2(3), 222-235. https://doi.org/10.5502/ijw.v2i3.4

\section{Honourable mention}

Henderson, L.W., \& Knight, T. (2012). Integrating the hedonic and eudaimonic perspectives to more comprehensively understand wellbeing and pathways to wellbeing. International Journal of Wellbeing, 2(3), 196-221. https://doi.org/10.5502/ijw.v2i3.3

\section{Winner}

Norrish, J. M., Williams, P., O'Connor, M., \& Robinson, J. (2013). An applied framework for positive education. International Journal of Wellbeing, 3(2), 147-161.

https://doi.org/10.5502/ijw.v3i2.2 


\section{Honourable mention}

McCann, C. M., Beddoe, E., McCormick, K., Huggard, P., Kedge, S., Adamson, C., \& Huggard, J. (2013). Resilience in the health professions: A review of recent literature. International Journal of Wellbeing, 3(1), 60-81. https://doi.org/10.5502/ijw.v3i1.4

\section{Winner}

Schueller, S. M., Kashdan, T. B., \& Parks, A. C. (2014). Synthesizing positive psychological interventions: Suggestions for conducting and interpreting meta-analyses. International Journal of Wellbeing, 4(1), 91-98. https://doi.org/10.5502/ijw.v4i1.5

\section{Honourable mention}

Hone, L. C., Jarden, A., Schofield, G. M., \& Duncan, S. (2014). Measuring flourishing: The impact of operational definitions on the prevalence of high levels of wellbeing. International Journal of Wellbeing, 4(1), 62-90. https://doi.org/10.5502/ijw.v4i1.4

\section{Winner}

Capaldi, C. A., Passmore, H.-A., Nisbet, E. K., Zelenski, J. M., \& Dopko, R. L. (2015). Flourishing in nature: A review of the benefits of connecting with nature and its application as a wellbeing intervention. International Journal of Wellbeing, 5(4), 1-16. https://doi.org/10.5502/ijw.v5i4.449

\section{Honourable mention}

Eger, R. J., \& Maridal, J. H., (2015). A statistical meta-analysis of the wellbeing literature. International Journal of Wellbeing, 5(2), 45-74. https://doi.org/10.5502/ijw.v5i2.4

\section{Winner}

Butler, J., \& Kern, M. L. (2016). The PERMA-Profiler: A brief multidimensional measure of flourishing. International Journal of Wellbeing, 6(3), 1-48. https://doi.org/10.5502/ijw.v6i3.526

\section{Honourable mention}

Adler, A. \& Seligman, M. E. P. (2016). Using wellbeing for public policy: Theory, measurement, and recommendations. International Journal of Wellbeing, 6(1), 1-35.

https://doi.org/10.5502/ijw.v6i1.429

\section{Winner}

Lomas, T. (2017). The spectrum of positive affect: A cross-cultural lexical analysis. International Journal of Wellbeing, 7(3), 1-18. https://doi.org/10.5502/ijw.v7i3.608

\section{Honourable mention}

Buchanan, A. \& Kern, M. L. (2017). The benefit mindset: The psychology of contribution and everyday leadership. International Journal of Wellbeing, 7(1), 1-11. https://doi.org/10.5502/ijw.v7i1.538

\section{Joint-winner}

Kim, H., Doiron, K., Warren, M. A., \& Donaldson, S. I. (2018). The international landscape of positive psychology research: A systematic review. International Journal of Wellbeing, 8(1), 50-70. https://doi.org/10.5502/ijw.v8i1.651 


\section{Joint-winner}

Hendriks, T., Schotanus-Dijkstra, M., Hassankhan, A, Graafsma, T., Bohlmeijer, E., \& de Jong, J. (2018). The efficacy of positive psychology interventions from non-Western countries: A systematic review and meta-analysis. International Journal of Wellbeing, 8(1), 71-98.

https://doi.org/10.5502/ijw.v8i1.711

\section{Winner}

Lahti, E., (2019). Embodied fortitude: An introduction to the Finnish construct of sisu.

International Journal of Wellbeing, 9(1), 61-82. https://doi.org/10.5502/ijw.v9i1.672

\section{Joint-honourable mention}

Gleason, T. R., \& Narvaez, D. (2019). Beyond resilience to thriving: Optimizing child wellbeing. International Journal of Wellbeing, 9(4), 59-78. https://doi.org/10.5502/ijw.v9i4.987

\section{Joint-honourable mention}

Pentti, S., Fagerlund, A., \& Nyström, P. (2019). Flourishing families: Effects of a positive psychology intervention on parental flow, engagement, meaning and hope. International Journal of Wellbeing, 9(4), 79-96. https://doi.org/10.5502/ijw.v9i4.1003

\section{Winner}

Bono, G., Reil, K., \& Hescox, J. (2020). Stress and wellbeing in college students during the COVID19 pandemic: Can grit and gratitude help? International Journal of Wellbeing, 10(3), 39-57. https://doi.org/10.5502/ijw.v10i3.1331

\section{Honourable mention}

Leibowitz, K., \& Vittersø, J. (2020). Winter is coming: Wintertime mindset and wellbeing in Norway. International Journal of Wellbeing, 10(4), 35-54. https://doi.org/10.5502/ijw.v10i4.935

We wish to congratulate the winners and express our sincere gratitude to the hundreds of authors that have submitted their excellent research to us.

\section{Looking forward 10 years}

We now end with more lofty ambitions for the next 10 years. It is our hope that:

1. We help more emerging academics into important editing and publishing roles

2. We encourage constructive debate about key issues in wellbeing research

3. We publish tools and resources that are useful for practitioners, policy makers and interested members of the public

4. We make the publishing process stress free, simple, transparent and efficient to better serve our authors

5. We do more to encourage thoroughly interdisciplinary scholarship on wellbeing

\section{Acknowledgments}

We sincerely thank our past funders for making our commitment to open access possible: The Vic Davis Memorial Trust, The Open Polytechnic of New Zealand, Hamilton College, The South Australian Health and Medical Research Institute, and the Centre for Positive Psychology at the University of Melbourne. 
Also, a big thanks to our editorial team. The co-editors: Dan Weijers, Aaron Jarden, Meg Warren, Tim Lomas, and Mariano Rojas. The past co-editors: Nattavudh Powdthavee, Steve Wu, Lindsay G. Oades, and Gavin Slemp. The advisory board: Stephen Wu, Lindsay G. Oades, Roger Crisp, Paul Dolan, Bruno S. Frey, Daniel Gilbert, Irwin Goldstein, Carol Graham, Dan Haybron, John F. Helliwell, Simon Keller, Simon Kemp, Richard Kraut, Stephen Palmer, Richard D. Parry, Mozaffar Qizilbash, Toni Ronnow Rasmussen, Ken Sheldon, David Sobel, Michael Steger, Torbjörn Tännsjö, and Dianne Vella-Brodrick. The section editors: Anna Sutton, Nicholas Agar, Erik Angner, Ian Bache, Lisa Bortolotti, Ben Bradley, George Burns, Carla Crespo, Ramon Das, Orin Davis, Dale Dorsey, Michalis Drouvelis, Elizabeth Dunn, Owen Flanagan, Suzy Green, Chris Heathwood, Paul E. Jose, Mohsen Joshanloo, Georgios Kavetsos, Simon Luechinger, Michael McBride, Philip S. Morrison, Evgeny Osin, Acacia C. Parks, Nattavudh Powdthavee, William Ransome, Daniel Russel, Claudia Senik, Tim Sharp, Professor Angus Skinner, Alena Slezackova, Timothy T.C. So, Margarita Tarragona, Neil Thin, Jingping Xu. And so many reviewers, authors, and readers - too many to list here.

\section{Authors}

Dan Weijers

The University of Waikato

dan.weijers@waikato.ac.nz

Aaron Jarden

The University of Melbourne

\section{References}

van der Deijl, W. (2016). What happiness science can learn from John Stuart Mill. International Journal of Wellbeing, 6(1), 164-179. https://doi.org/10.5502/ijw.v6i1.464

Weijers, D., \& Jarden, A. (2017). The International Journal of Wellbeing: An Open Access Success Story. In: Jhangiani, R. S., and Biswas-Diener, R. (eds.) Open: The Philosophy and Practices that are Revolutionizing Education and Science. Pp. 181-194. London: Ubiquity Press. https://doi.org/10.5334/bbc.n. License: CC-BY 4.0

Weijers, D., Jarden, A., \& Powdthavee, N. (2011). Promoting research on wellbeing. International Journal of Wellbeing, 1(1), 1-3. https://doi.org/10.5502/ijw.v1i1.21 